\title{
The structure and context of male and female song in White-throated Dippers
}

\author{
Lucy Magoolagan $^{1}$ (D) Peter J. Mawby ${ }^{1}$. Flora A. Whitehead ${ }^{1} \cdot$ Stuart P. Sharp ${ }^{1}$
}

Received: 1 September 2017 / Revised: 14 July 2018 / Accepted: 12 October 2018 / Published online: 19 October 2018

(c) The Author(s) 2018

\begin{abstract}
Female song in birds is more widespread than previously thought but remains poorly studied. Relatively few researchers have compared the structure and function of female song with that of conspecific males, especially in non-duetting species. Here we investigate male and female song in the White-throated Dipper (Cinclus cinclus; hereafter 'Dipper'), a highly territorial and largely monogamous passerine with a complex song in both sexes. The songs of individually marked birds were recorded over a 3-year period in order to compare the acoustic structure and production of song in males and females at different stages of the breeding cycle. No differences were found in the complexity, frequency or temporal characteristics of male and female songs. However, unpaired males recorded early in the breeding season sang more complex songs than males that were paired up and nest-building or whose breeding attempts were underway, suggesting that male song is used for mate attraction. By contrast, females sang most often during aggressive encounters with birds from outside their territory. Furthermore, males sang throughout the breeding season, when they are highly territorial, whereas females rarely sang after laying had begun. Together, these results support findings from other species that song structure varies with context and suggest that female song in Dippers may be used primarily in mate or territory defence.
\end{abstract}

Keywords Acoustic structure $\cdot$ Birdsong $\cdot$ Cinclus cinclus $\cdot$ Vocal communication $\cdot$ Territorial defence $\cdot$ Mate defence

\section{Zusammenfassung}

\section{Struktur und Kontext vom männlichen und weiblichen Gesang bei Wasseramseln}

Der Gesang von weiblichen Vögeln ist weiter verbreitet als bislang vermutet, jedoch wurde dieser bisher kaum untersucht. Nur relativ wenige Forscher haben zum jetzigen Zeitpunkt die Struktur und Funktion des weiblichen Vogelgesanges mit dem der Männchen verglichen, vor allem bei Arten ohne Duett-Gesang. Wir untersuchen hier den männlichen und weiblichen Gesang der Wasseramsel (Cinclus cinclus), eine sehr territoriale und weitgehend monogame Singvogelart mit einem komplexen Gesang bei beiden Geschlechtern. Über einen Zeitraum von drei Jahren wurde der Gesang individuell markierter Vögel aufgezeichnet, um die akustische Struktur und Produktion des weiblichen und männlichen Gesanges während verschiedener Phasen des Brutzyklus zu vergleichen. Zwischen den Geschlechtern konnten keine Unterschiede in der Komplexität, Frequenz oder im zeitlichen Verlauf des Gesanges gefunden werden. Jedoch sangen unverpaarte Männchen, die während der frühen Brutzeit aufgezeichnet wurden, komplexer als verpaarte Männchen, die bereits mit dem Nestbau oder mit der Brut begonnen hatten. Dies lässt vermuten, dass der männliche Gesang der Partnerwerbung dient. Im Vergleich dazu setzten Weibchen ihren Gesang am häufigsten während aggressiver Auseinandersetzungen mit anderen Vögeln außerhalb ihres Territoriums ein. Weiterhin sangen sehr territoriale Männchen während der gesamten Brutzeit, während Weibchen nur noch selten nach dem Beginn des Geleges sangen. Zusammengefasst unterstützen diese Ergebnisse die bisherigen Beobachtungen bei anderen Vogelarten, deren Gesangstruktur je nach Kontext variiert, und lassen vermuten, dass der weibliche Gesang der Wasseramsel meist nur für die Partner- und Revierverteidigung verwendet wird.

Communicated by S. Kipper.

Lucy Magoolagan

lucy.magoolagan@hotmail.co.uk

Extended author information available on the last page of the article 


\section{Introduction}

The two main functions of song in male birds are mate attraction and territorial defence (Catchpole and Slater 2008). Song is thought to be an honest signal of male quality because it is costly to produce (Searcy and Yasukawa 1996; Nowicki et al. 1998; Gil and Gahr 2002; Catchpole and Slater 2008). While several studies have shown that song production may not be demanding in terms of metabolic energy consumption (Franz and Goller 2003; Ward et al. 2004), singing at a high amplitude or from obvious song posts can increase predation risk (Gil and Gahr 2002) and time spent singing is time taken away from other activities such as foraging (Oberweger and Goller 2001). The complexity of male song is widely considered to be a sexually selected trait in many species (Searcy and Andersson 1986; Catchpole 1987; Macdougall-Shackleton 1997; but see Byers and Kroodsma 2009) and, in some cases, the size of regions of the brain such as the high vocal centre is positively correlated with song complexity and the ability to learn a larger quantity of songs or song components (Nowicki et al. 2002; Pfaff et al. 2007; but see Gahr 2007; Hall et al. 2011).

Repertoire size is a measure of the number of either unique songs or syllable types used by an individual (Hiebert et al. 1989; Potvin and Clegg 2015). In many species, males and females are sensitive to the diversity of syllables within a song, and repertoire size is thought to play an important role in intra-sexual selection, mate choice and reproductive stimulation (Searcy and Yasukawa 1996; Nowicki et al. 1998; Gil and Gahr 2002). Correlations have been found between repertoire size and a number of individual and life history traits including condition (Kipper et al. 2006), territory size (Buchanan and Catchpole 1997) and tenure (Hiebert et al. 1989; but see Beecher et al. 2000), parental effort (Buchanan and Catchpole 2000) and reproductive success (Potvin et al. 2013). Furthermore, several studies have shown that song complexity (Järvi 1983; Nelson and Croner 1991; Ammer and Capp 1999) and specific acoustic characteristics (Catchpole 1983; Nagle and Couroux 2000) can change with motivation, season or age. For instance, it has been shown that migratory and sedentary Blackcap (Sylvia atricapilla) populations have different intra- and inter-sexual song characteristics (Collins et al. 2009).

Female song was once thought to be rare but recent work has shown that it is widespread, especially in the tropics and Australasia (Odom et al. 2014; Hall and Langmore 2017). Most research has focussed on duetting species (Langmore 1998; Slater and Mann 2004; Logue and Krupp 2016) but far less is known about the function of solo female song in other birds. In some cases there is evidence for a role in territory or resource defence, including in monogamous species with year-round territoriality (Brunton and Li 2006; Price et al. 2008; Tobias et al. 2016) and polygynous species such as the Red-winged Blackbird (Agelaius phoeniceus), in which females defend their own sub-territories within a male's territory (Beletsky 1982). In other cases it may reduce the incidence of polygyny (Langmore 1998), coordinate breeding activities (Ritchison 1983) or maintain pair bonds (Hovekamp 1996). Mate attraction has rarely been reported as the function of female song, although this has been suggested for the polygynandrous Alpine Accentor (Prunella collaris) (Langmore et al. 1996). However, female song can be easily overlooked in species where individuals only sing for a small window of the breeding season, or in monomorphic species where it is difficult to distinguish between the sexes (Langmore 1998; Hahn et al. 2013; Odom and Benedict 2018). Moreover, few studies have directly compared the acoustic structure of male and female song, or the behavioural and seasonal contexts in which the two sexes sing. In House Wrens (Troglodytes aedon), it has been shown that males use song for mate attraction but both sexes can sing to defend resources or to communicate with their partner (Krieg and Getty 2016). Such comparisons may offer important insights into the function and evolution of female song in other non-duetting species.

Here, we investigate the structure and potential functions of song in male and female White-throated Dippers (Cinclus cinclus, hereafter 'Dippers'). The Dipper is a sexually monochromatic, riverine songbird that defends linear territories year-round and is one of relatively few passerines of the North Temperate Zone in which both sexes are known to sing regularly (Tyler and Ormerod 1994; Odom et al. 2014; Odom and Benedict 2018). Song in dippers has been reported year-round with the exception of the late summer months when birds undergo a post-breeding moult (Tyler and Ormerod 1994). High rates of song have been noted, particularly during territory settlement and defence, early in the breeding season (Tyler and Ormerod 1994). The song has been described as 'a very sweet rippling warble' with female song 'a less sweet series of whistles and disconnected units', but no formal analysis of song has been carried out to date (Cramp and Simmons 1988; Villain et al. 2017). We recorded and analysed the songs of individually marked birds in a wild population in order to compare: (1) the acoustic structure of male and female song, (2) the acoustic structure of song produced at different stages of the reproductive cycle, and (3) the seasonal patterns in song production for males and females. 


\section{Methods}

\section{Song recording and spectrogram production}

Song was recorded from January to July (2014-2016) in a marked population of 40-50 pairs of Dippers in the River Lune catchment near Sedbergh, Cumbria, UK ( $54^{\circ} 323^{\prime} \mathrm{N}$, $\left.2^{\circ} 528^{\prime} \mathrm{W}\right)$. Each year, all unmarked adults are trapped and ringed using mist nets or hand nets placed over the nest; nestlings are ringed when they are 9 days old. Every individual is given a unique combination of three plastic colour rings and a standard British Trust for Ornithology metal ring. All individuals were identifiable from their unique combination of colour rings and had been sexed at capture according to their wing length (Andersson and Wester 1971; Svensson 1992); for most individuals, sexing could be confirmed from observations of reproductive behaviour [e.g. incubation is carried out by the female only (Tyler and Ormerod 1994)] and in no cases was there a discrepancy between the two methods. Each year, all nests within the study population were found and closely monitored to record parental identity, the timing and outcome of reproduction, and a number of behavioural and life history traits. Within this population, some pairs remain together throughout the winter but other individuals start to pair up in January or early February. Nest-building typically begins in late February or March and most clutches are laid in March and April; the female alone incubates the eggs (for 16-17 days) but both parents then provision the offspring throughout the nestling period (21-22 days), with the last nests fledging in June or early July. Dippers are socially monogamous with a low frequency of extrapair paternity (Øigarden et al. 2010), and adults in the study population typically breed for 2-3 years but exceptionally up to 8 years (S. P. S., unpublished data).

Songs were recorded from distances of $10-15 \mathrm{~m}$ using a Sennheiser ME66-K6 shotgun microphone with a Rycote Softie windshield and a standard pistol grip connected to a Marantz PMD661 MKII solid state recorder with a sampling frequency of $44.1 \mathrm{kHz}$; files were stored in WAV format. The site was visited daily throughout the breeding season in 2014 and from January to May in other years, with only a few exceptions due to extreme weather conditions; sampling effort was spread evenly across the field site throughout these periods, with each territory visited at least once per week. Recordings were made opportunistically after May 2015 and 2016. Upon sighting a given individual, the observer waited $30 \mathrm{~min}$; if the bird did not produce song in that time the observer moved onto the next one. If a focal individual (male or female) began to sing this was recorded until the bird: (1) disappeared and could not be relocated; (2) changed behaviour, e.g. to foraging;
(3) remained silent for $30 \mathrm{~min}$; or (4) had been recorded for more than $1 \mathrm{~h}$ and a large amount of song had been collected. Complete songs were defined as having a minimum of a 0.5 -s pause between them. The mean $( \pm S D)$ pause between syllables was $0.23 \pm 0.05 \mathrm{~s}$ (range $=0.11-0.33$; $n=10$ songs from each of 45 individuals). The mean pause between songs was $6.50 \pm 3.70 \mathrm{~s}$ (range $=0.6-64.0 ; n=10$ pairs of successive songs from 26 individuals).

\section{Acoustic structure}

A minimum of ten songs was recorded for each of 34 males and 11 females. In order to standardise the number of songs analysed (see below) but maximise the number of individuals included, analyses were restricted to ten songs per bird. If more songs than this had been recorded for a particular individual, ten were selected after those with the lowest signal to noise ratio had been excluded. For each individual, all ten songs were recorded in the same 2- to 3-week period and birds were categorised according to their breeding stage during this time (see below). A number of complexity, frequency and temporal song characteristics were then measured for each individual and compared between males at different breeding stages, and between males and females recorded at the same stage. These measures were as follows: syllable diversity and versatility (complexity); maximum, minimum and average peak frequency (frequency); and average song length, average syllables per second and song rate (temporal).

Syllable repertoire size in dippers appears to be large. We carried out preliminary analyses of this trait using simple enumeration (Botero et al. 2008), but when plotting the cumulative number of unique syllables against the total number of syllables analysed, the curve for only one out of 45 individuals reached an asymptote. One individual, for which 22 songs had been recorded and analysed, was found to produce in excess of 157 unique syllables with no asymptote reached. Rather than estimating syllable repertoire size, we therefore calculated the number of unique syllables produced in a standardised sample of ten songs (hereafter 'syllable diversity'), the minimum number of songs recorded of sufficient quality for analysis. This was considered a biologically meaningful sample as individuals rarely produce more than ten songs in a single bout, hence most receivers would typically hear fewer songs before responding (L. M., unpublished data).

Syllable diversity was measured using visual and auditory inspections of spectrograms (Fig. 1), produced using Avisoft SASLab Pro, version 5.2.08 (Specht 1993), with a 512-point fast Fourier transform length and Hamming window function, $75 \%$ frame size, a $87.5 \%$ window overlap $86-\mathrm{Hz}$ frequency resolution and $1.45-\mathrm{ms}$ time resolution. All songs were also high pass filtered at $1 \mathrm{kHz}$ to remove low 
(a)

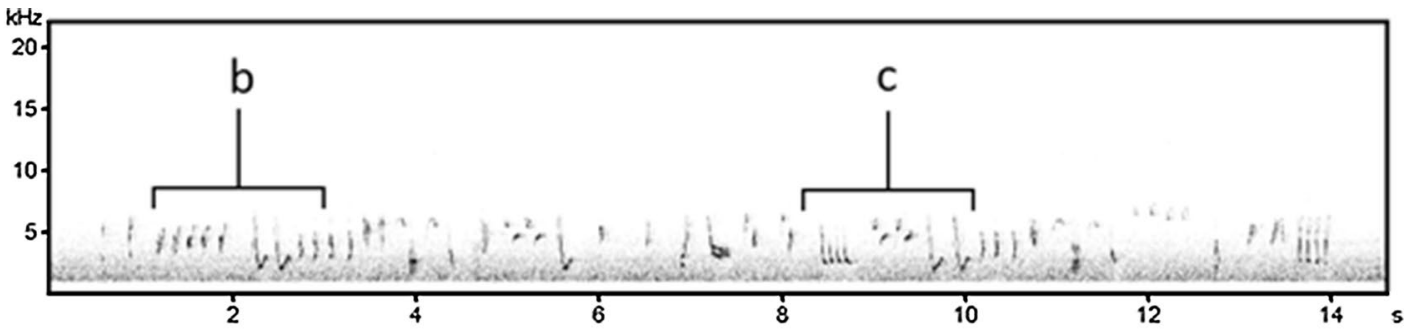

(b)

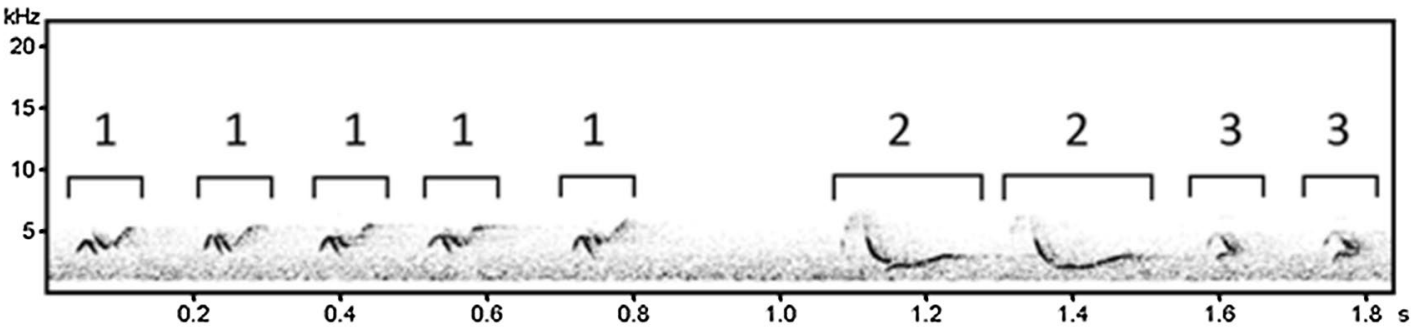

(c)

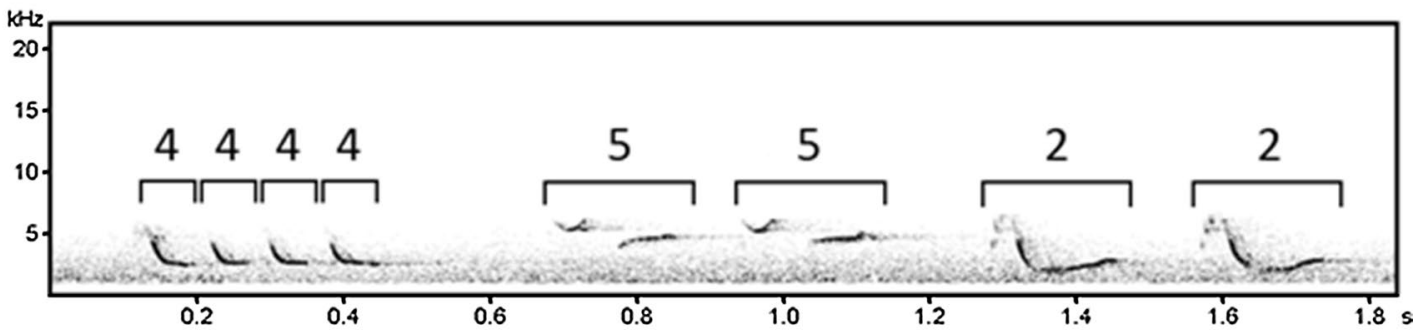

(d)

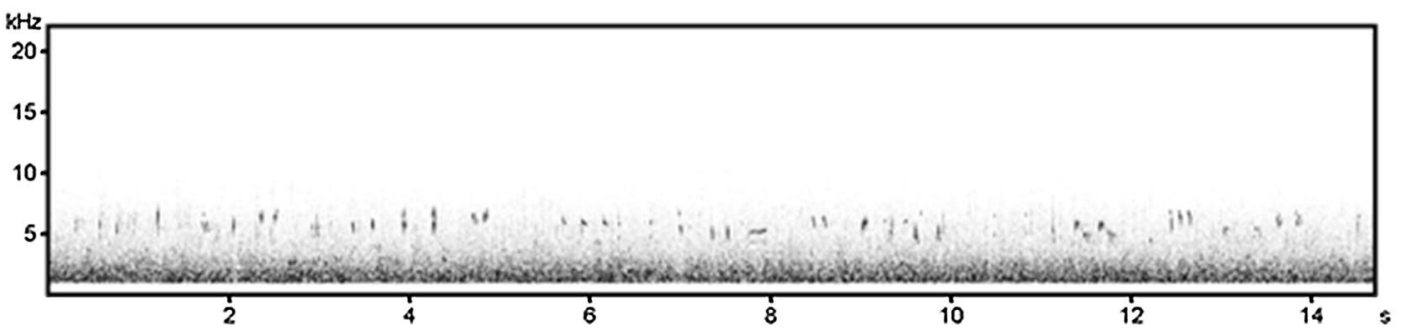

Fig. 1 Spectrograms of male White-throated Dipper (Cinclus cinclus, hereafter 'Dipper)' song: a full song; followed by sections of that song (b) and (c) that represent the resolution at which songs were analysed (Avisoft settings as stated in "Methods"). Syllables are num-

frequency background noise (e.g. the sound of the river); this threshold was chosen because preliminary analyses revealed that a small number of Dipper songs contained elements with a frequency as low as $1.03 \mathrm{kHz}$. First, elements were identified (the smallest continuous tracing on a spectrogram) that were then grouped into syllables where appropriate. Syllables comprised multiple elements, none of which was ever produced in isolation; the pause between elements within a syllable was less than $0.1 \mathrm{~s}$ and therefore smaller than the minimum pause between syllables. Measurements were first carried out in full by one observer (L. M.), with each unique syllable being given an identifier. This process was then validated by a second observer (S. P. S.) using a sub-sample of songs and applying the same procedures, but without knowing the previous results. Using one full song from each of bered; 1 and 5 show how elements are grouped together to form syllables. Syllables can be repeated straight away (e.g. 1) or appear later in the same song (e.g. 2). A spectrogram of female Dipper song (d) is also included for comparison

ten individuals, $93.9 \%$ of all syllables $(=279 / 297)$ were catalogued in the same way by both observers; there was no significant difference in the total number of unique syllables per song measured by the two (paired $t$-test: $t=1.309, d f=9$, $P=0.223$; nine measures differed by 1 and the other differed by 2). Versatility was calculated by dividing the number of unique syllables found within one song by the total number of syllables found in that song (Järvi 1983). This measure was then averaged across each of an individual's ten songs.

A range of frequency and temporal characteristics was also measured using Luscinia version 2.02.10.15; spectrograms were produced using a fast Fourier transformation with a Gaussian analysis window, $80 \%$ spectrogram overlap, $10-\mathrm{kHz}$ maximum frequency, $5-\mathrm{ms}$ frame duration, 1-ms time step and 2-dB noise removal (Lachlan 2007). All 
measurements were based on peak frequency, which is the frequency of maximum intensity (i.e. highest amplitude) for each syllable; this was calculated from 50 measurements taken across every syllable in each song (using the standard settings in Luscinia). The maximum, minimum and average (per syllable) peak frequency (in kilohertz) were taken for each individual from the total sample of songs. Average song length (in seconds) was calculated across the ten songs to the nearest $0.05 \mathrm{~s}$; average syllables per second was calculated by dividing the number of syllables found in each song by song length and then averaging over the ten songs analysed for each individual. Song rate was calculated using the number of complete songs produced within a single 30-min period of observation for each individual during which the bird sang at least once, starting at the time when the bird was first observed singing.

\section{Breeding stage}

For every individual, the breeding stage was classified according to the paired status and reproductive stage of the bird at the time of recording. Three mutually exclusive categories were defined: (1) 'solo' songs were those of individuals recorded in January or February that had yet to be seen with a partner; (2) 'pre-breeding' songs were given by individuals that had been seen with the same partner on at least two occasions foraging, prospecting or nest-building together; and (3) 'breeding' songs were those of individuals that had paired up and had nests at the laying, incubation or nestling stage. The identity of any conspecifics that could be seen by the observer, other than the breeding partner of the singer, was recorded whenever possible. Each individual's ten songs were recorded during the same breeding stage (the first in which the complete sample size of ten songs was obtained), so comparisons of songs produced at different stages were not pseudoreplicated (males, $n=10$ solo, 14 pre-breeding and 10 breeding; females, $n=2$ solo, 8 pre-breeding and 1 breeding). Insufficient recordings were obtained to allow comparisons of the songs produced by the same individual (male or female) at different breeding stages. Statistical comparisons between the sexes were restricted to pre-breeding individuals due to the small sample of females recorded singing at other stages; similarly, statistical comparisons between stages were restricted to males. Solo females are rarely encountered as they are highly mobile (S. P. S., unpublished data) and only a single breeding female was ever recorded singing.

\section{Female song context and seasonal trends}

To further investigate the possible function of female song, all observations over the data collection period were classified according to the behavioural context in which the song was produced: (1) 'aggression' described situations in which a singing female was observed in the presence of at least one conspecific other than her partner and during which antagonistic behaviour (e.g. chasing or fighting) was observed; (2) 'nest-building' was used for songs recorded during the prospecting or nest-building phase of the breeding season, which were almost always produced in the presence of the female's mate; and (3) 'other' was used for the small number of songs recorded that could not be classified into either of the other contexts. The use of song in these contexts was then compared over the season by using the context in which each female was first recorded singing in each month; only one female produced song in more than one context per month, and only on a single occasion.

To investigate seasonal variation in song production, the proportion of individuals of each sex that sang at least once during a sampling session was calculated for every day of the 2014 season (mean number of individuals sampled per day $=4.59 \pm 2.44$ ). Data from 2015 and 2016 were excluded due to insufficient coverage during the latter part of the season in those years. All dates were converted to a Julian date (i.e. $1=1$ January).

\section{Statistical analysis}

To compare the acoustic structure of male and female song, $t$ tests and Mann-Whitney $U$ tests were carried out for normally and non-normally distributed song characteristics, respectively. The songs of males in different contexts were compared using one-way ANOVAs for parametric data and Kruskal-Wallis tests for non-parametric data, with post hoc Tukey tests or Dunn tests, respectively. All analyses were carried out in R, version 3.2.2 (R Core Team et al. 2015). We used the Benjamini-Hochberg false discovery rate procedure to control for multiple testing and provide adjusted $p$ values accordingly (Benjamini and Hochberg 1995).

\section{Results}

\section{Acoustic structure, sex and breeding stage}

There was no significant difference between the songs of pre-breeding males and pre-breeding females in any of the complexity, frequency or temporal characteristics measured (Table 1; Fig. 2). However, males singing at different breeding stages used significantly different numbers of unique syllables (Table 2); post hoc tests showed that solo males had a significantly higher syllable diversity than pre-breeding males $(q=3.48, p=0.02)$ or breeding males ( $q=3.48, p=0.02$; Table 2; Fig. 2a). Furthermore, 
Table 1 A comparison of the means $( \pm \mathrm{SD})$ of a range of complexity, frequency and temporal characteristics of song in male $(n=14)$ and female $(n=8)$ White-throated Dippers (Cinclus cinclus, hereafter 'Dipper')

\begin{tabular}{|c|c|c|c|c|}
\hline Measure & Male & Female & Test statistic $(t, W)$ & $p$ \\
\hline Syllable diversity ${ }^{\mathrm{a}}$ & $61.5 \pm 15.7$ & $82.5 \pm 29.3$ & $t=-1.88$ & 0.091 \\
\hline Versatility $^{\mathrm{b}}$ & $0.52 \pm 0.07$ & $0.55 \pm 0.054$ & $t=-0.90$ & 0.379 \\
\hline Maximum peak frequency $(\mathrm{kHz})$ & $8.08 \pm 0.52$ & $7.85 \pm 0.28$ & $W=47.5$ & 0.585 \\
\hline Minimum peak frequency $(\mathrm{kHz})$ & $1.59 \pm 0.36$ & $1.54 \pm 0.46$ & $t=-0.26$ & 0.797 \\
\hline Average peak frequency $(\mathrm{kHz})$ & $4.91 \pm 0.19$ & $4.93 \pm 0.19$ & $t=0.21$ & 0.836 \\
\hline Average song length (s) & $6.39 \pm 1.79$ & $8.02 \pm 3.87$ & $W=47.0$ & 0.570 \\
\hline Average syllables per second ${ }^{c}$ & $3.77 \pm 0.69$ & $3.53 \pm 0.43$ & $W=64.5$ & 0.585 \\
\hline Song rate ${ }^{\mathrm{d}}$ (songs $30 \mathrm{~min}^{-1}$ ) & $9.79 \pm 7.02$ & $16.8 \pm 9.32$ & $W=30.5$ & 0.092 \\
\hline
\end{tabular}

Data are for individuals recorded in the 'pre-breeding' stage only

${ }^{\text {a }}$ Syllable diversity is the number of unique syllables produced in a standardised sample of ten songs

${ }^{b}$ Versatility was calculated by dividing the number of unique syllables found within one song by the total number of syllables found in that song, then averaging across each of an individual's ten songs

${ }^{c}$ Average syllables per second was calculated by dividing the number of syllables found in each song by song length and then averaging over the ten songs

${ }^{\mathrm{d}}$ Song rate was calculated using the number of complete songs produced within a single 30-min period of observation for each individual during which the bird sang at least once, starting at the time when the bird was first observed singing versatility was significantly lower in songs from breeding males than in those from males at other breeding stages (versus solo males, $q=3.48, p<0.001$; versus pre-breeding males, $q=3.48, p=0.01$; Table 2; Fig. 2b).

There was no difference in any of the frequency characteristics or in the average length of male songs produced at different breeding stages (Table 2). The number of syllables per second was higher in the songs of breeding males than in those of males from the other stages (Fig. 2c), and song rate was higher in solo males than in pre-breeding or breeding males (Fig. 2d); however, these differences were marginally non-significant after correcting for multiple testing (Table 2).

\section{Female song context and seasonal trends}

Female song was frequently recorded during aggressive encounters in the early part of the season (Fig. 3). In the encounters during which all individuals present were identified, the female was singing during an interaction with a lone female on five occasions, a lone male on two occasions and a pair on three occasions. The remaining two observations involved unringed individuals, so their sex was unknown. Some females also sang during the nest-building period and occasionally in other contexts, but song was less frequently recorded later in the season (Fig. 3). This seasonal decline was also apparent from the decrease in the proportion of observed females recorded singing as the season progressed (Fig. 4b). The proportion of observed males recorded singing also peaked early in the season but remained at a relatively high level throughout (Fig. 4a).

\section{Discussion}

No differences were detected in the acoustic structure of songs produced by male and female Dippers. This may have been because analyses were restricted to pre-breeding individuals and songs produced during this stage might have played a similar role in the two sexes. For example, prebreeding song may function primarily in territorial defence, which is carried out by both males and females (Tyler and Ormerod 1994; Logue and Krupp 2016), or the coordination of breeding activities. Alternatively, there may be sexual differences in song characteristics that were not measured here. Studies of other species have reported a difference between males and females in several acoustic parameters that may facilitate sex discrimination, though such differences are sometimes subtle (Yamaguchi 1998; Pavlova et al. 2005; Geberzahn and Gahr 2011); our sample sizes were relatively small and further analyses are required, especially of songs at other breeding stages and, ideally, including comparisons of the songs produced by the same individual at different stages.

Solo males were found to use significantly more unique syllables within their songs than males at other breeding stages; they also sang at a higher rate, although this trend was no longer significant after correcting for multiple testing. Breeding males produced songs with significantly lower versatility than those of other males and there was a non-significant tendency for these songs to contain fewer syllables per second, suggesting greater repetition. Variation in song characteristics according to an individual's breeding status has been reported in several species (Ballentine et al. 2003; Hall and Langmore 2017) and presumably relates to the motivational state of the singer. In Dippers, the differences in complexity and song rate between solo males and breeding males suggest that the former 

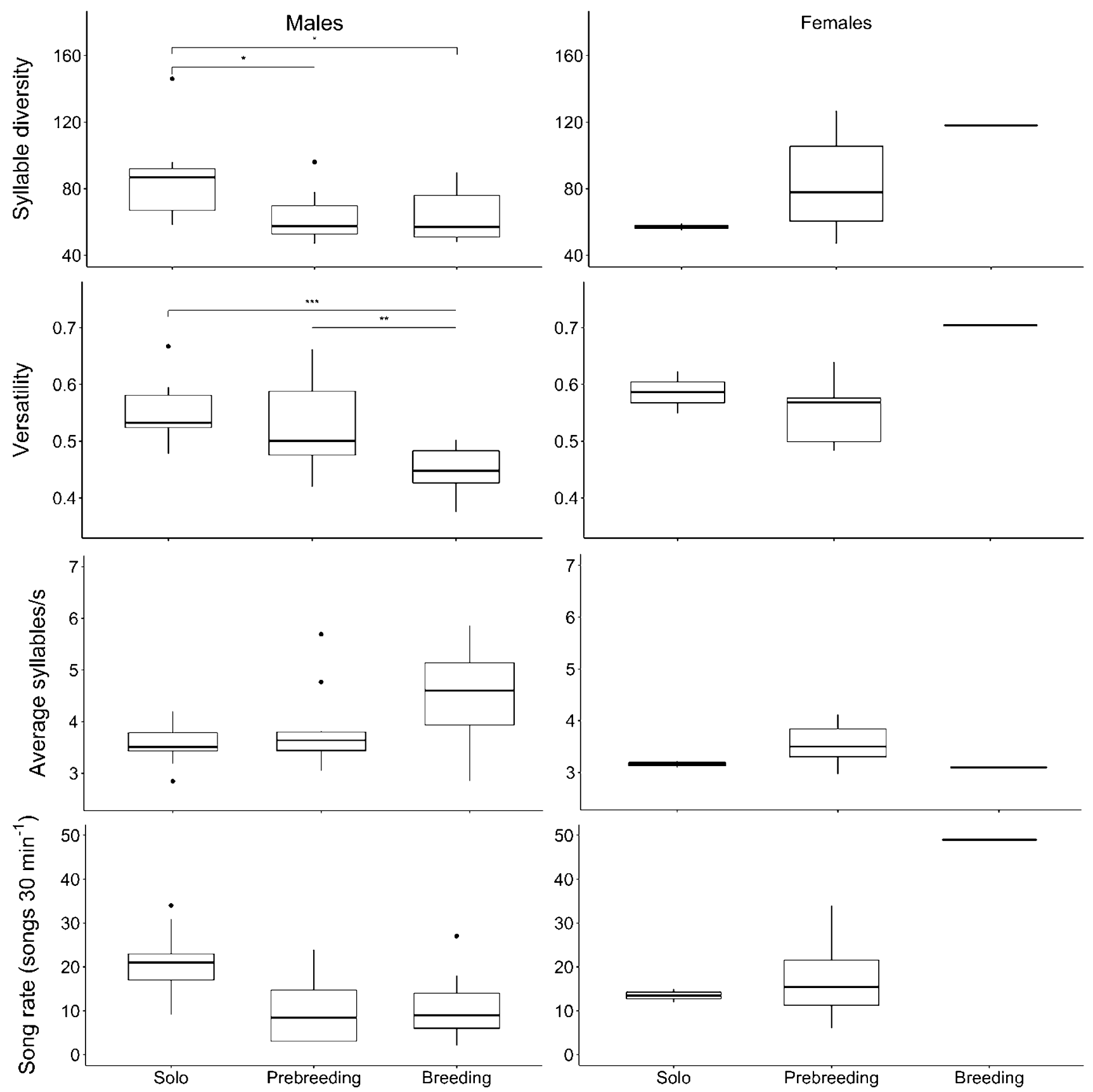

Fig. 2 A comparison of song characteristics in male and female Dippers at different breeding stages: a syllable diversity, b versatility, c average syllables per second, and $\mathbf{d}$ song rate. Boxes show the median, first and third quartiles; upper and lower whiskers extend to the highest and lowest values that are within $1.5 \times$ the inter-quartile range. Data beyond the end of the whiskers are outliers and plotted as individual points. Syllable diversity is the number of unique syllables produced in a standardised sample of ten songs. Versatility was calculated by dividing the number of unique syllables found within one song by the total number of syllables found in that song, then

may use song for mate attraction. Singing is thought to be an expensive behaviour, in terms of increased predation risk and reduced foraging time, if not metabolic costs (Mougeot and

averaging across each of an individual's ten songs. Average syllables per second was calculated by dividing the number of syllables found in each song by song length and then averaging over the ten songs. Song rate was calculated using the number of complete songs produced within a single 30-min period of observation for each individual during which the bird sang at least once, starting at the time when the bird was first observed singing. Sample sizes for each sex at each breeding stage are as follows: solo males $(n=10)$, pre-breeding males $(n=14)$, breeding males $(n=10)$, solo females $(n=2)$, pre-breeding females $(n=8)$ and breeding females $(n=1)$

Bretagnolle 2000; Gil and Gahr 2002; Franz and Goller 2003; Ward et al. 2004), and solo males may compensate for this through the increased probability of securing a mate. Measures 
Table 2 A comparison of the means ( \pm SD) of a range of complexity, frequency and temporal characteristics of songs produced by male Dippers at different breeding stages

\begin{tabular}{|c|c|c|c|c|c|c|}
\hline \multirow[t]{2}{*}{ Measure } & \multicolumn{3}{|l|}{ Male songs } & \multirow[t]{2}{*}{ Test statistic } & \multirow[t]{2}{*}{$p$} & \multirow[t]{2}{*}{$p$ adjusted } \\
\hline & Solo (10) & Pre-breeding (14) & Breeding (10) & & & \\
\hline Syllable diversity ${ }^{a}$ & $85.4 \pm 25.1$ & $61.5 \pm 15.7$ & $61.2 \pm 17.8$ & $F=5.40$ & 0.010 & 0.039 \\
\hline Versatility $^{\mathrm{b}}$ & $0.55 \pm 0.053$ & $0.52 \pm 0.07$ & $0.45 \pm 0.05$ & $F=8.38$ & 0.001 & 0.010 \\
\hline Maximum peak frequency $(\mathrm{kHz})$ & $8.42 \pm 0.68$ & $8.08 \pm 0.52$ & $8.01 \pm 0.49$ & $\chi^{2}=2.13$ & 0.346 & 0.461 \\
\hline Minimum peak frequency $(\mathrm{kHz})$ & $1.52 \pm 0.50$ & $1.59 \pm 0.36$ & $1.40 \pm 0.42$ & $F=0.60$ & 0.553 & 0.553 \\
\hline Average peak frequency $(\mathrm{kHz})$ & $4.89 \pm 0.42$ & $4.91 \pm 0.19$ & $4.75 \pm 0.30$ & $F=0.85$ & 0.438 & 0.500 \\
\hline Average song length (s) & $8.33 \pm 3.00$ & $6.39 \pm 1.79$ & $6.08 \pm 2.10$ & $\chi^{2}=4.44$ & 0.106 & 0.168 \\
\hline Average syllables per second ${ }^{c}$ & $3.51 \pm 0.37$ & $3.77 \pm 0.69$ & $4.50 \pm 0.93$ & $\chi^{2}=6.84$ & $\mathbf{0 . 0 3 3}$ & 0.066 \\
\hline Song rate ${ }^{\mathrm{d}}$ (songs $30 \mathrm{~min}^{-1}$ ) & $19.4 \pm 9.05$ & $9.79 \pm 7.02$ & $10.7 \pm 7.57$ & $\chi^{2}=7.32$ & 0.026 & 0.066 \\
\hline
\end{tabular}

Sample sizes are given in parentheses

Significant differences $(p<0.05)$ are shown in bold. $p$-values are provided before and after adjustment using the Benjamini-Hochberg false discovery rate procedure to control for multiple testing

${ }^{\text {a }}$ Syllable diversity is the number of unique syllables produced in a standardised sample of ten songs

${ }^{b}$ Versatility was calculated by dividing the number of unique syllables found within one song by the total number of syllables found in that song, then averaging across each of an individual's ten songs

${ }^{c}$ Average syllables per second was calculated by dividing the number of syllables found in each song by song length and then averaging over the ten songs

${ }^{\mathrm{d}}$ Song rate was calculated using the number of complete songs produced within a single 30-min period of observation for each individual during which the bird sang at least once, starting at the time when the bird was first observed singing

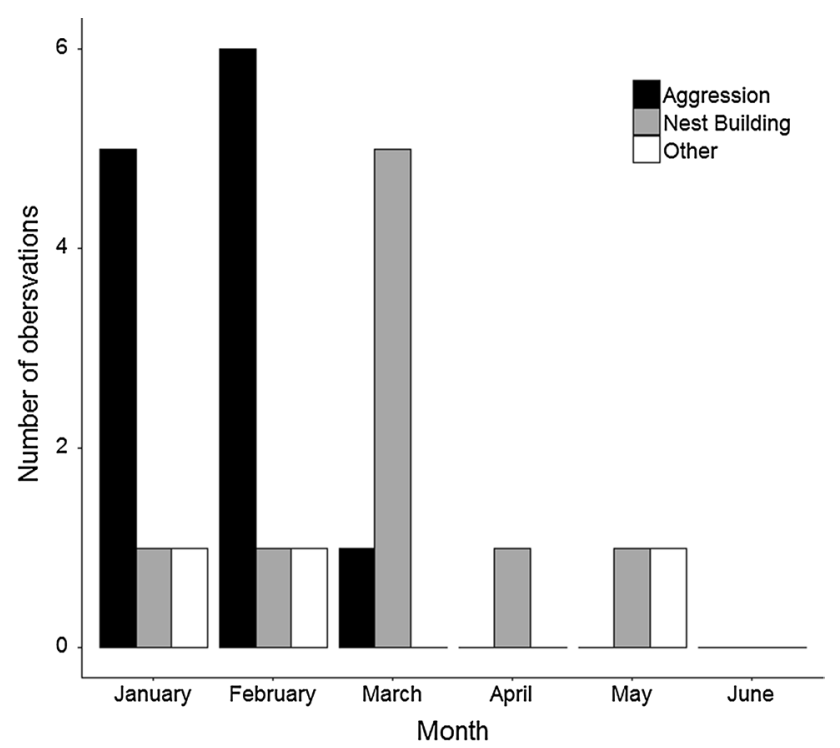

Fig. 3 The number of observations of female Dippers singing in different behavioural contexts during each month of the breeding season. Within each month, observations correspond to different females because only the first context in which a given female produced song is shown: 'Aggression' (black) describes females within their own territory that sang in the presence of an intruder, i.e. not their partner; Nest-building (grey) describes females recorded singing whilst prospecting or building a nest with their partner; and Other (white) describes females that sang in all other contexts

of song complexity such as syllable diversity or repertoire size are widely reported as sexually selected traits in other species (Catchpole and Slater 2008), and a similar role has been suggested for versatility (e.g. Järvi 1983). Further work on sexual selection in dipper song should investigate the fitness consequences of variation in complexity but might also focus on performance-based song traits, such as consistency, which are thought to be important in some species (Podos 1997; Botero et al. 2010; but see Kroodsma 2017).

Observations of females singing were most frequent during the start of the breeding season when territory boundaries are being established between neighbours. Most female song was recorded during aggressive encounters, usually involving another female, during which song presumably functions in defence, either of a territory or a mate. Members of a pair may only defend against same-sex intruders, which would increase the efficiency of defence (Langmore 1998). This behaviour has been observed in Northern Cardinals (Cardinalis cardinalis), in which female song was shown not to deter intrusions by new males but was thought to deter other females (McElroy and Ritchison 1996). In our study, female song was also recorded during nest-building when the male was present, and may play a role in pair-bonding or the coordination of breeding activities, as has been shown in Black-headed Grosbeaks (Pheucticus melanocephalus) (Ritchison 1983). Finally, on three occasions females were recorded singing when neither aggressive interactions nor nest-building were taking place. In two cases, the same female was observed singing in the presence of a male who was not her partner; this was at a time when egg-laying was imminent and it is possible that this female may have attempted to advertise her fertility to increase chances of extra-pair copulation (Baptista et al. 


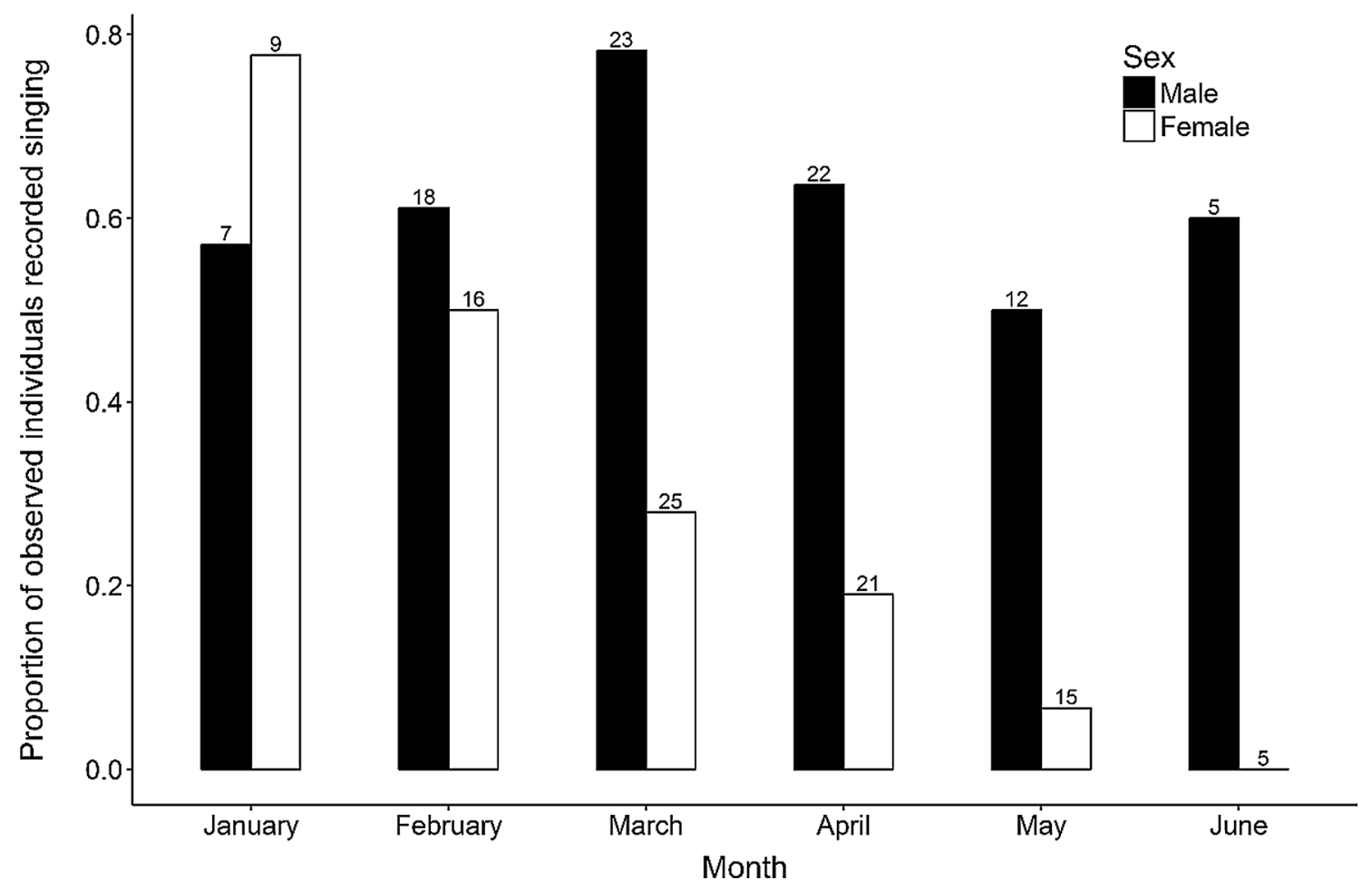

Fig. 4 The proportion of observed individuals recorded singing for each month of the breeding season for male and female Dippers. Proportions were calculated across all observed individuals per month

1993). Another female was observed singing in May whilst accompanied by her partner and when their chicks were a few days from fledging; this female may have been using song to advertise her fertility in preparation for a second clutch (Baptista et al. 1993). Only 12 solo females were observed throughout the entire study, eight of which were recorded singing (two with sufficient regularity to be included in our sample). While our results suggest that mate attraction may not be the primary function of female song, it may be that solo females do sing to attract males but are rarely encountered.

The seasonal decline in the production of song by females is likely due to the energetic constraints imposed by parental care, particularly during incubation and brooding (Brunton et al. 2008). Singing on or near the nest may also compromise offspring survival by making nests more conspicuous to predators (Kleindorfer et al. 2016). In contrast, male song was recorded regularly throughout the breeding season, which is in keeping with a role in territorial defence and mate guarding. Our fieldwork ended shortly after each breeding season, and future research on singing behaviour in the second half of the year may shed further light on the different contexts in which both males and females sing.

Finally, it is worth noting that the average peak frequency used by both sexes is similar to that reported for calls in this species, which are concentrated within a narrow frequency range of 4-6.5 kHz (Tyler and Ormerod 1994). This is likely according to whether or not they were recorded singing at least once in that month. Sample sizes are denoted above the bars for each sex in every month

to enable communication over long distances given the low frequency background noise of their riverine environment (Tyler and Ormerod 1994), and it has also been reported that individuals sing more frequently in the quieter parts of their territory (Magoolagan 2012). Even so, the complexity of song has the potential to be masked by the noise of running water, and it may be that the frequent visual signals given by dippers, such as dipping, wing flashing and blinking, play a role in increasing perception of song characteristics (Tyler and Ormerod 1994; Johnstone 1996).

In conclusion, our study provides one of the relatively few direct comparisons of the acoustic structure and seasonality of male and female song in a non-duetting species, together with evidence of context-specific song characteristics in males. The results support previous findings that song structure can vary within a species according to the breeding status of the singer. The observed differences in seasonality between the sexes may simply reflect the energetic constraints of breeding in females, but may also arise from differences in song function between males and females. While no structural differences were detected, sample sizes were relatively small and comparisons were restricted to the pre-breeding stage; further analyses including playback experiments are required to better understand functionality. Furthermore, it is still unknown whether song is a sexually selected trait in female birds (Pavlova et al. 2005), and recent findings that 
female song was likely present in the early ancestors of songbirds raise the question of why this trait has since been lost in some species (Odom et al. 2014; Hall and Langmore 2017; Odom and Benedict 2018). Analyses of the relationship between song complexity and fitness would shed further light on the function and evolution of female song in dippers.

\section{Data availability}

The datasets analysed during the current study are available from the corresponding author on reasonable request. The sound recordings are archived at https://doi. org/10.7479/3kce-9mkh.

\section{Compliance with ethical standards}

Ethical approval All procedures performed were in accordance with the ethical standards of Lancaster University. The trapping and ringing of birds was licensed by the British Trust for Ornithology.

Open Access This article is distributed under the terms of the Creative Commons Attribution 4.0 International License (http://creativeco mmons.org/licenses/by/4.0/), which permits unrestricted use, distribution, and reproduction in any medium, provided you give appropriate credit to the original author(s) and the source, provide a link to the Creative Commons license, and indicate if changes were made.

\section{References}

Ammer FK, Capp MS (1999) Song versatility and social context in the Bobolink. Condor 101(3):686-688

Andersson JS, Wester SAL (1971) Length of wing, bill, and tarsus as a character of sex in the Dipper Cinclus cinclus. Ornis Scand 2(1):75-79

Ballentine B, Badyaev A, Hill GE (2003) Changes in song complexity correspond to periods of female fertility in Blue Grosbeaks (Guiraca caerulea). Ethology 109(1):55-66

Baptista LF, Trail PW, DeWolfe BB, Morton ML (1993) Singing and its functions in female White-crowned Sparrows. Anim Behav 46:511-524

Beecher MD, Campbell SE, Burt JM, Hill CE, Nordby JC (2000) Song type matching between neighbouring Song Sparrows. Anim Behav 59:21-27

Beletsky L (1982) Aggressive response to "self" songs by female Redwinged Blackbirds, Agelaius phoeniceus. Can J Zool 61:462-465

Benjamini Y, Hochberg Y (1995) Controlling the false discovery rate: a practical and powerful approach to multiple testing. J R Stat Soc Ser B (Methodol) 57(1):289-300

Botero CA, Mudge AE, Koltz AM, Hochachka WM, Vehrencamp SL (2008) How reliable are the methods for estimating repertoire size?. Ethology 114(12):1227-1238

Botero CA, Rossman RJ, Caro LM, Stenzler LM, Lovette IJ, De Kort SR, Vehrencamp SL (2010) Syllable type consistency is related to age, social status, and reproductive success in the Tropical Mockingbird. Anim Behav 77(3):701-706

Brunton DH, Li X (2006) The song structure and seasonal patterns of vocal behavior of male and female Bellbirds (Anthornis melanura). J Ethol 24(1):17-25
Brunton DH, Evans B, Cope T, Ji W (2008) A test of the dear enemy hypothesis in female New Zealand Bellbirds (Anthornis melanura): female neighbors as threats. Behav Ecol 19(4):791-798

Buchanan KL, Catchpole CK (1997) Female choice in the Sedge Warbler Acrocephalus schoenobaenus: multiple cues from song and territory quality. Proc R Soc B Biol Sci 264:521-526

Buchanan KL, Catchpole CK (2000) Song as an indicator of male parental effort in the Sedge Warbler. Proc Biol Sci R Soc 267(1441):321-326

Byers BE, Kroodsma DE (2009) Female mate choice and songbird song repertoires. Anim Behav 77(1):13-22

Catchpole CK (1983) Variation in the song of the Great Reed Warbler Acrocephalus arundinaceus in relation to mate attraction and territorial defence. Anim Behav 31(4):1217-1225

Catchpole CK (1987) Bird song, sexual selection and female choice. Trends Ecol Evol 2(4):94-97

Catchpole CK, Slater PJB (2008) Bird song-biological themes and variations. Cambridge University Press, Cambridge

Collins SA, de Kort SR, Pérez-Tris J, Tellería JL (2009) Migration strategy and divergent sexual selection on bird song. Proc R Soc B Biol Sci 276(1656):585-590

Cramp S, Simmons KEL (1988) Handbook of the birds of Europe, the Middle East and North Africa: Tyrant Flycatchers to thrushes v.5: the birds of the western Palearctic: Tyrant Flycatchers to thrushes, vol 5. Oxford University Press, Oxford

Franz M, Goller F (2003) Respiratory patterns and oxygen consumption in singing Zebra Finches. J Exp Biol 206:967-978

Gahr M (2007) Sexual differentiation of the vocal control system of birds. Adv Genet 59:67-105

Geberzahn N, Gahr M (2011) Undirected (solitary) birdsong in female and male Blue-capped Cordon-bleus (Uraeginthus cyanocephalus) and its endocrine correlates. PLoS One 6(10):1-11

Gil D, Gahr M (2002) The honesty of bird song: multiple constraints for multiple traits. Trends Ecol Evol 17(3):133-141

Hahn AH, Krysler A, Sturdy CB (2013) Female song in Blackcapped Chickadees (Poecile atricapillus): acoustic song features that contain individual identity information and sex differences. Behav Proc 98:98-105

Hall ML, Langmore NE (2017) Fitness costs and benefits of female song. Frontiers Media, Lausanne. https://doi.org/10.3389/9782-88945-258-3

Hall ZJ, MacDougall-Shackleton SA, Osorio-Beristain M, Murphy TG (2011) Male bias in the song control system despite female bias in song rate in Streak-backed Orioles (Icterus pustulatus). Brain Behav Evol 76(3-4):168-175

Hiebert SM, Stoddard PK, Arcese P (1989) Repertoire size, territory acquisition and reproductive success in the Song Sparrow. Anim Behav 37:266-273. https://doi.org/10.1016/00033472(89)90115-2

Hovekamp N (1996) Intersexual vocal communication in the Redwinged Blackbird (comunicación vocal intersexual en Agelaius phoeniceus). J Field Ornithol 67(3):376-383

Järvi T (1983) The evolution of song versatility in the Willow Warbler Phylloscopus trochilus: a case of evolution by intersexual selection explained by the "female's choice of the best mate". Ornis Scand 14(2):123-128

Johnstone RA (1996) Multiple displays in animal communication: 'backup signals' and 'multiple messages'. Philos Trans R Soc B Biol Sci 351(1337):329-338. https://doi.org/10.1098/rstb.1996.0026

Kipper S, Mundry R, Sommer C, Hultsch H, Todt D (2006) Song repertoire size is correlated with body measures and arrival date in Common Nightingales, Luscinia megarhynchos. Anim Behav 71(1):211-217. https://doi.org/10.1016/j.anbehav.2005.04.011

Kleindorfer S, Evans C, Mahr K (2016) Female in-nest chatter song increases predation. Biol Lett 12(1):18-21. https://doi. org/10.1098/rsbl.2015.0513 
Krieg CA, Getty T (2016) Not just for males: females use song against male and female rivals in a temperate zone songbird. Anim Behav 113:39-47. https://doi.org/10.1016/j.anbehav.2015.12.019

Kroodsma D (2017) Birdsong "performance" studies: a sad commentary. Anim Behav 133:209-210

Lachlan RF (2007) Luscinia: software for bioacoustic archiving, measurement and analysis. http://rflachlan.github.io/Luscinia/

Langmore NE (1998) Functions of duet and solo songs of female birds. Trends Ecol Evol 13(4):136-140

Langmore N, Davies N, Hatchwell BJ, Hartley IR (1996) Female song attracts males in the Alpine Accentor Prunella collaris. Proc Biol Sci 263(1367):141-146

Logue DM, Krupp DB (2016) Duetting as a collective behavior. Front Ecol Evol 4:7. https://doi.org/10.3389/fevo.2016.00007

Macdougall-Shackleton SA (1997) Sexual selection and the evolution of song repertoires. In: Nolan V, Ketterson ED, Thompson CF (eds) Current ornithology. Springer, Boston, pp 81-124. https:// doi.org/10.1007/978-1-4757-9915-6_3

Magoolagan L (2012) Song site choice and ambient noise in Whitethroated Dippers and a comparative analysis of vocalisations in the family Cinclidae. Dissertation, Manchester Metropolitan University

McElroy D, Ritchison G (1996) Effect of mate removal on singing behavior and movement patterns of female Northern Cardinals. Wilson Bull 108(3):550-555

Mougeot F, Bretagnolle V (2000) Predation as a cost of sexual communication in nocturnal seabirds: an experimental approach using acoustic signals. Anim Behav 60(5):647-656. https://doi. org/10.1006/anbe.2000.1491

Nagle L, Couroux C (2000) The influence of song mode on responses of male American Redstarts. Ethology 106:1049-1055. https:// doi.org/10.1046/j.1439-0310.2002.00781.x

Nelson DA, Croner LJ (1991) Song categories and their functions in the Field Sparrow (Spizella pusilla). Auk 108(1):42-52

Nowicki S, Peters S, Podos J (1998) Song learning, early nutrition and sexual selection in songbirds. Integr Comp Biol 38(1):179-190. https://doi.org/10.1093/icb/38.1.179

Nowicki S, Searcy WA, Peters S (2002) Brain development, song learning and mate choice in birds: a review and experimental test of the "nutritional stress hypothesis". J Comp Physiol A 188(1112):1003-1014. https://doi.org/10.1007/s00359-002-0361-3

Oberweger K, Goller F (2001) The metabolic cost of birdsong production. J Exp Biol 204(19):3379-3388

Odom KJ, Benedict L (2018) A call to document female bird songs: applications for diverse fields. Auk 135(2):314-325

Odom KJ, Hall ML, Riebel K, Omland KE, Langmore NE (2014) Female song is widespread and ancestral in songbirds. Nat Commun 5:3379. https://doi.org/10.1038/ncomms4379

Øigarden T, Borge T, Lifjeld JT (2010) Extrapair paternity and genetic diversity: the White-throated Dipper Cinclus cinclus. J Avian Biol 41(3):248-257. https://doi.org/10.1111/j.1600-048X.2009.04847.x

Pavlova D, Pinxten R, Eens M (2005) Female song in European Starlings: sex differences, complexity, and composition. Condor 107(3):559-569
Pfaff JA, Zanette L, MacDougall-Shackleton SA, MacDougall-Shackleton EA (2007) Song repertoire size varies with HVC volume and is indicative of male quality in Song Sparrows (Melospiza melodia). Proc R Soc Lond B Biol Sci 274(1621):2035-2040. https://doi.org/10.1098/rspb.2007.0170

Podos J (1997) A performance constraint on the evolution of trilled vocalizations in a songbird family (Passeriformes: Emberizidae). Evolution 51(2):537-551

Potvin DA, Clegg SM (2015) The relative roles of cultural drift and acoustic adaptation in shaping syllable repertoires of island bird populations change with time since colonization. Evolution 69(2):368-380. https://doi.org/10.1111/evo.12573

Potvin DA, Crawford PW, Macdougall-Shackleton SA, MacDougallShackleton EA (2013) Song repertoire size, not territory location, predicts reproductive success and territory tenure in a migratory songbird. Can J Zool 93:627-633. https://doi.org/10.1139/ cjz-2015-0039

Price J, Yunes-Jiménez L, Osorio-Beristain M, Omland KE, Murphy TG (2008) Sex-role reversal in song? Females sing more frequently than males in the Streak-backed Oriole. Condor 110(2):387-392. https://doi.org/10.1525/cond.2008.8430

R Core Team, R Development Core Team R (2015) In: RDC Team (ed) R: a language and environment for statistical computing. $\mathrm{R}$ Foundation for Statistical Computing, Vienna, p 409. https://doi. org/10.1007/978-3-540-74686-7

Ritchison G (1983) The function of singing in female Black-headed Grosbeaks (Pheucticus melanocephalus): family-group maintenance. Auk 100(1):105-116

Searcy WA, Andersson M (1986) Sexual selection and the evolution of song. Annu Rev Ecol Syst 17:507-533

Searcy WA, Yasukawa K (1996) Song and female choice. In: Kroodsma D, Miller EH (eds) Ecology and evolution of acoustic communication in birds, 1st edn. Cornell University Press, New York

Slater P, Mann N (2004) Why do the females of many bird species sing in the tropics? J Avian Biol 35(4):289-294

Specht R (1993) Avisoft-SASLab Pro. Available at: http://www.aviso ft.com/. Accessed 17 Oct 2018

Svensson L (1992) Identification guide to European passerines, 4th edn. British Trust for Ornithology, Norfolk

Tobias JA, Sheard C, Seddon N, Meade A, Cotton AJ, Nakagawa S (2016) Territoriality, social bonds, and the evolution of communal signaling in birds. Front Ecol Evol 4:74. https://doi.org/10.3389/ fevo.2016.00074

Tyler SJ, Ormerod SJ (1994) The dippers, 1st edn. Poyser, Staffordshire

Villain AS, Mahamoud-Issa M, Doligez B, Vignal C (2017) Vocal behaviour of mates at the nest in the White-throated Dipper Cinclus cinclus: contexts and structure of vocal interactions, pairspecific acoustic signature. J Ornithol 158(4):897-910. https:// doi.org/10.1007/s10336-017-1449-4

Ward S, Lampe HM, Slater PJB (2004) Singing is not energetically demanding for Pied Flycatchers, Ficedula hypoleuca. Behav Ecol 15(3):477-484. https://doi.org/10.1093/beheco/arh038

Yamaguchi A (1998) Can a sexually dimorphic learned birdsong be used for male-female recognition? Behaviour 135(7):833-844

\section{Affiliations}

\section{Lucy Magoolagan $^{1}{ }^{1} \cdot$. Peter J. Mawby ${ }^{1} \cdot$ Flora A. Whitehead ${ }^{1}$. Stuart P. Sharp ${ }^{1}$}

1 Lancaster University, Bailrigg, Lancaster LA1 4YW,

Lancashire, UK 